University of Montana

ScholarWorks at University of Montana

10-1997

\title{
Competition and Facilitation: a Synthetic Approach to Interactions in Plant Communities
}

\author{
Ragan M. Callaway \\ University of Montana - Missoula, Ray.Callaway@mso.umt.edu \\ Lawrence R. Walker
}

Follow this and additional works at: https://scholarworks.umt.edu/biosci_pubs

Part of the Biology Commons

Let us know how access to this document benefits you.

\section{Recommended Citation}

Callaway, Ragan M. and Walker, Lawrence R., "Competition and Facilitation: a Synthetic Approach to Interactions in Plant Communities" (1997). Biological Sciences Faculty Publications. 98.

https://scholarworks.umt.edu/biosci_pubs/98

This Article is brought to you for free and open access by the Biological Sciences at ScholarWorks at University of Montana. It has been accepted for inclusion in Biological Sciences Faculty Publications by an authorized administrator of ScholarWorks at University of Montana. For more information, please contact scholarworks@mso.umt.edu. 


\title{
COMPETITION AND FACILITATION: A SYNTHETIC APPROACH TO INTERACTIONS IN PLANT COMMUNITIES
}

\author{
Ragan M. Callaway ${ }^{1}$ and Lawrence R. WalkeR ${ }^{2}$ \\ ${ }^{1}$ Division of Biological Sciences, University of Montana, Missoula, Montana 59812 USA \\ ${ }^{2}$ Department of Biological Science, University of Nevada, Las Vegas, Las Vegas, Nevada 89154 USA
}

\begin{abstract}
Interactions among organisms take place within a complex milieu of abiotic and biotic processes, but we generally study them as solitary phenomena. Complex combinations of negative and positive interactions have been identified in a number of plant communities. The importance of these two processes in structuring plant communities can best be understood by comparing them along gradients of abiotic stress, consumer pressure, and among different life stages, sizes, and densities of the interacting species. Here, we discuss the roles of life stage, physiology, indirect interactions, and the physical environment on the balance of competition and facilitation in plant communities.
\end{abstract}

Key words: community; competition; facilitation; indirect interactions; interactions; life stage; plant community; positive interactions.

\section{INTRODUCTION}

Our understanding of how interactions among plants affect community structure is largely based on studies in which specific mechanisms have been isolated and analyzed. By this approach, ecologists have shown that resource competition (Connell 1983, Schoener 1983), allelopathy (Rice 1984, Williamson 1990), and facilitation (Hunter and Aarssen 1988, Callaway 1995) have important effects on community organization. But facilitative and competitive mechanisms do not act in isolation from each other in nature, and by co-occurring within the same community, and even between the same individuals, they may produce complex and variable effects.

Complex combinations of negative and positive interactions operating between plant species appear to be widespread in nature, and are not restricted to particular communities or biomes (Callaway 1995). Documenting the occurrence of these interactions and their specific mechanisms have been important steps toward a synthetic perspective of interactions in plant communities. The next step, understanding facilitation in the context of general conceptual models of plant community structure that are now dominated by competition (see Bertness and Leonard 1997) may be more difficult. For example, the balance of facilitation and competition appears to vary with the life stages of the interacting species (Walker and Vitousek 1991, Kellman and Kading 1992, Chapin et al. 1994, Pugnaire et al. 1996, Walker, in press), physiologies of the interacting species (Callaway et al. 1996, Holmgren et al. 1997), in-

Manuscript received 1 December 1995; accepted 16 December 1996; final version received 6 February 1997. For reprints of this Special Feature, see footnote 1, page 1945. direct interactions with other neighbors (Miller 1994), and the intensity of abiotic stress experienced by the interacting species (Bertness and Callaway 1994). Our purpose here is to synthesize the literature germane to the balance of competition and facilitation in plant communities.

\section{DISCUSSION}

\section{The co-occurrence of competition and facilitation}

Early studies that provided evidence for complex combinations of negative and positive interactions appeared to inadvertently encounter one process while investigating the other. For example, in a study designed to determine the relative importance of shade from trees vs. root competition on suppressing conifer seedlings, Shirley (1945) found that with light levels $>20 \%$ of irradiance in the open, the benefits of shade from the overstory trees compensated for the negative effects of root interference. Ellison and Houston (1958) noted that herbaceous productivity under aspens greatly exceeded that in the adjacent open grassland, but found that trenching aspen roots increased understory herbaceous productivity even more.

Callaway et al. (1991) found that herbaceous biomass under individual Quercus douglasii canopies in oak savannas and woodlands in California varied continuously, from understories with much higher biomass than nearby open grassland to understories with much lower biomass than open grassland. They found that all $Q$. douglasii trees, regardless of understory biomass, added considerable amounts of nutrients to the soil beneath their canopies and, as root exclosure experiments showed, had the potential to facilitate understory herbs. However, the manifestation of nutrient facili- 
tation depended on the root architecture of individual trees. Trees with low fine-root biomass in the upper soil horizons (and predawn water potentials that suggested root access to the water table) had strong, positive effects on understory biomass. In contrast, trees with high fine-root biomass in the upper soil horizons (and that probably did not reach at the water table) had strong negative effects on understory biomass. Experimental root exclusion increased understory biomass under trees with high shallow-root biomass, but had no effect on understory biomass beneath trees with low shallow-root biomass. Thus, the overall effect of an overstory tree on its herbaceous understory was determined by the balance of both facilitation and competition. In a similar experiment, Aguiar et al. (1992) found that reduction of root competition under shrubs in the Patagonian steppe revealed the otherwise undetectable positive effects of the shrub canopy.

Walker and Chapin (1987) and Chapin et al. (1994) found evidence for complex combinations of facilitation and competition in two similar environments in Alaska. In an interior floodplain, Walker and Chapin (1987) demonstrated the existence of facilitation (primarily by adding nitrogen to the soil) by Alnus tenuifolia on Salix alaxensis and Populus balsamifera seedlings in greenhouse experiments and in the field. However, under natural conditions, $S$. alaxensis, $P$. balsamifera, and Picea glauca grew more poorly in alder stands than in pre-alder successional stages. In other experiments, they found that root interference and shading in alder stands were much more influential on the other species than was nutrient addition, and overrode the effects of facilitation. In Glacier Bay, Chapin et al. (1994) found that Alnus sinuata also had both positive and negative effects on the nutrient status and growth of Picea sitchensis seedlings on glacial moraines. But, in contrast to results from the floodplain site, the overall effect of Alnus was positive: $P$. sitchensis seedlings that were planted in alders accumulated more than twice the biomass and acquired significantly higher leaf concentrations of nitrogen and phosphorus than did seedlings planted in pre-alder successional stages. Root trenching in Alnus stands in Glacier Bay further increased the positive effect, demonstrating that competitive and facilitative mechanisms were operating simultaneously; in contrast to the interior floodplain site, the facilitative effects of alder on spruce overrode root interference in the field.

In field experiments on Mount Saint Helens, Morris and Wood (1989) and Wood and del Moral (1987) found that Lupinus lepidus, the initial pioneer on the barren pyroclastic flows, reduced the survival of two invading species, Anaphalis margaritacea and fireweed (Epilobium angustifolium), in the first year. However, seedlings of both invading species that survived within lupine patches grew larger than in control treatments in both years, and the survival of both species was higher in lupine patches in the second year. They concluded that a balance of facilitative and inhibitory effects determined successional establishment. The balance between facilitation and competition was emphasized in later studies, when del Moral and Bliss (1993) found that Anaphalis, Epilobium, and Hypochaeris seedlings were less associated with living Lupinus lepidus than expected by chance, but that rapid invasion of nutrient-rich patches occurred soon after the senescence of Lupinus plants.

Shifts in facilitation and competition among aerenchymous wetland plants occur as temperatures change in anaerobic substrates. Myosotis laxa, a small herb common in wetlands of the northern Rockies, benefited from soil oxygenation when grown with Typha latifolia at low soil temperatures in greenhouse experiments (Callaway and King 1996). At higher soil temperatures, the significant effects of Typha on soil oxygen disappeared (presumably because of increased microbial and root respiration) and the interaction between Typha and Myosotis became competitive. In the field, the overall effect of Typha on Myosotis was positive, as Myosotis growing next to transplanted cattails were larger and produced more fruit that those isolated from cattails.

Walker and Vitousek (1991) found that the direct effects of Myrica faya, an invasive tree in Hawai 'i, on the native tree Metrosideros polymorpha were both positive and negative. Soils enriched by the nitrogenfixing Myrica increased Metrosideros seedling growth, and shade from Myrica trees enhanced Metrosideros germination and seedling survival. However, Myrica litter appeared to physically inhibit Metrosideros germination, root competition reduced Metrosideros survival and growth, and the net effect was negative.

Co-occurring facilitative and competitive effects between the same species occur in other systems and often vary in time or space (Hay 1986, Eldridge et al. 1991, Aguiar and Sala 1994, Belsky 1994, Callaway 1994, Callaway et al. 1996, Walker in press), but the factors that determine the balance between positive and negative are poorly understood. Factors that have been considered include life stage, plant density, speciesspecific physiology, indirect interactions, and abiotic stress.

\section{Life stage and the balance of competition and facilitation}

Life stages (e.g., seed, seedling, juvenile, pre-reproductive adult, reproductive adult, senescent adult) may affect the outcome of interactions between plant species. For example, the effect of Lupinus lepidus, previously described, on survival of other herbs was negative in the first year, positive in the second year, and appeared even more positive after the death of Lupinus (Morris and Wood 1989, del Moral and Bliss 1993). Life stage is a function of how long a plant has been at a site, growth rate, and longevity. Plant size and density are 
functions of life stage, and increases in either have been found to confer superior competitive ability (Goldsmith 1978, Keddy and Shipley 1989). Positive spatial associations between seedlings of one species and sheltering adults of another species are common, and have been widely referred to as the "nurse plant syndrome" (Niering et al. 1963, Turner et al. 1966, 1969, Steenberg and Lowe 1969, 1977). The importance of facilitation of seedlings by adults of other species has been supported by studies in deserts (Jordan and Nobel 1979, 1981, McAuliffe 1986, 1988, Franco and Nobel 1988, 1989, Valiente-Banuet et al. 1991 $a, b$, Valiente-Banuet and Ezcurra 1991, Arriaga et al. 1993), savannas and woodlands (Archer et al. 1988, Callaway 1992, Kellman and Kading 1992, Vetaas 1992, Callaway et al. 1996), tropical forests (Kellman and Miyanshi 1982, Kellman 1985, Guevara et al. 1986, 1992), mediterranean-climate shrubland (Fuentes et al. 1984), salt marshes (Bertness and Hacker 1994), and grasslands (Fowler 1988, Greenlee and Callaway 1996). In many of these cases, seedlings of beneficiary species are found spatially associated with nurse plants, whereas adults are not, which suggests that the balance of competition and facilitation shifts among the various life stages of the beneficiary and the benefactor.

Patterns of nurse plant mortality that have been observed in several systems indicate that some species that begin their lives as the beneficiaries of nurse plants become significant competitors with their former benefactors as they mature. McAuliffe (1984) found that young Larrea tridentata plants were disproportionately associated with dead Ambrosia dumosa, a species critical to the initial establishment of Larrea. Similarly, mature saguaros were associated disproportionately with dead paloverde trees, which commonly function as nurse plants to seedling saguaros (McAuliffe 1986). In the Tehuacan Valley of Mexico, Neobuxbaumia tetetzo, which is nursed by Mimosa luisana (Valiente-Banuet et al. 1991b), eventually suppresses the growth and reproduction of its benefactor (Flores-Martinez et al. 1994). Archer et al. (1988) found that once Prosopis glandulosa created habitat suitable for colonization by other woody perennials, the colonizers were able either to outcompete the original Prosopis nurse plant or to prevent it from reproducing in the clusters. Similar patterns have been reported in Texas savannas, where Juniperus virginiana trees are facilitated in early life stages by Quercus stellata (Archer and Rykiel 1994). As Juniperus trees mature, they overtop and kill $O$. stellata.

Kellman and Kading (1992) found that the strength of facilitative interactions may depend on the age of the benefactor. Densities of Pinus strobus and P. resinosa seedlings and saplings were six times greater under the canopies of mature ( $>35 \mathrm{yr}$ old) Quercus rubra than in open areas. A habitat manipulation experiment confirmed the primary role of shade in facilitating pine seedling establishment. However, the facilitative effect ap- peared to operate only for older $O$. rubra, because trees younger than $35 \mathrm{yr}$ old showed no preferential establishment beneath them. Similarly, Pugnaire et al. (1996) reported that understory production and plant diversity under the canopies of Retama sphaerocarpa, a dominant shrub in semiarid regions of Spain, increased significantly with shrub age and size.

These patterns and experiments suggest that the positive effects of benefactors are strong when beneficiaries are young and small. When the beneficiaries are older and larger, competitive interactions may dominate.

Plant density can also alter the balance between competition and facilitation. Thickets of early successional species often inhibit colonization by later successional species (Connell and Slatyer 1977, Niering et al. 1986, Walker 1993, Walker 1994, Berkowitz et al. 1995), whereas scattered individuals of thicket-forming species may have neutral or positive effects on the same latesuccessional species. For example, Picea seedlings transplanted into thickets of Alnus in Glacier Bay, Alaska grew better (facilitation) than seedlings planted into earlier successional stages away from Alnus (Chapin et al. 1994). Picea seedlings planted near isolated Alnus were not larger than solitary Picea (neutral). At a floodplain site in central Alaska, naturally occurring Picea seedlings were inhibited by thickets of Alnus (competition), but Picea seedlings were not affected by isolated Alnus (neutral) (Walker and Chapin 1987). Hence, the effects of Alnus thickets were always stronger than those of isolated Alnus, but the thickets were facilitative at Glacier Bay and competitive in central Alaska. High neighbor densities may resist invasion, but may also ameliorate harsh environments, stabilize soils, increase soil organic matter, moisture, and nutrients (Walker 1994), thereby facilitating the growth of other species that can establish there. These contrasting effects of neighbor density, or other life stage characteristics, may vary with abiotic stress.

Despite numerous examples of the influence of life stage on the balance of competition and facilitation, many facilitative relationships are not closely tied to life stage. For example, facilitative relationships between understory herbs and overstory savanna trees occur over a wide range of benefactor sizes and over the entire lifespan of the beneficiaries (Vetaas 1992, Callaway 1995).

To our knowledge, no experiments have been conducted to explore shifts in the balance of competition and facilitation over different life stages of interacting species (but compare results of Chapin et al. 1994 with Fastie 1995, or Walker and Vitousek 1991 with Aplet et al. in press). The potential for positive and negative interactions between two species to change as they grow older suggests that most studies of these interactions have been too short.

\section{Physiology and the balance of competition and facilitation}

Shifts in facilitation and competition on gradients of moisture and light may be connected with the hypothesis 
that plants cannot simultaneously adapt to shade and drought tolerance (Smith and Huston 1989, Huston 1994). However, many researchers have noted that some plant species grow better in the shade of others in dry habitats (the nurse plant phenomenon) than in moist habitats. In response to this apparent contradiction, Holmgren et al. (1997) developed a model that portrays the interplay between competition and facilitation on the basis of plant responses to water and light and the effects of plant canopies on microsite light and moisture. They argued that light limitation outweighs moisture limitation in mesic habitats, thus negating the possible favorable effects of slight increases in moisture under plant canopies. In contrast, moisture limitation is more important in xeric habitats than light limitation; thus, the slight decreases in understory light are outweighed by proportionally high increases in soil moisture. This model contributes considerably to understanding the balance of positive and negative interactions in some systems, and explains some of the experimental results just described. In contrast, however, Callaway et al. (1996) found that Pinus monophylla, an exceptionally droughttolerant species, was facilitated by Artemisia tridentata, but $P$. ponderosa, a less drought-tolerant species, was outcompeted by A. tridentata in the same locations (also see DeLucia et al. 1988).

\section{Indirect interactions and the balance of competition and facilitation}

Indirect interactions occur if a third species (or more species) modifies the interaction between two other species (Connell 1990). Miller (1994) argued that the success of species in a community is affected not only by direct interactions between species, but also by indirect interactions among groups of species (see also Adler and Morris 1994, Billick and Case 1994, Wootton 1994). Miller (1994) found that direct effects of five species in an old-field community were generally competitive (although some indirect effects were also negative), and indirect effects were generally positive. For example, the exceptionally good competitors, such as Ambrosia artemisifolia, had very strong negative effects on the moderately good competitors, Agropyron repens and Plantago lanceolata, which reduced the total competition experienced by poor competitors, such as Trifolium repens and Chenopodium album). In several cases, the magnitude of the indirect positive effect was greater than that of the direct negative effect, resulting in a facilitative overall effect. This apparently was because associate species suppressed intermediate competitors more than did focal species. Pennings and Callaway (1996) found that Cuscuta salina, a parasitic plant, indirectly facilitated Limonium californicum and Frankenia salina by suppressing Salicornia virginica, the competitive dominant in a California salt marsh. These studies demonstrate the importance of explicitly considering indirect interactions in studies of competition and facilitation.

\section{Abiotic stress and the balance of competition and facilitation}

Primary productivity generally decreases along gradients of increasing abiotic stress. Grime (1979) hypothesized that competition intensifies along an increasing gradient of primary productivity. Grime's hypothesis has been supported by some experimental analyses (Campbell and Grime 1992, Goldberg and Barton 1992, Pennings and Callaway 1992), although the generality of the model has been disputed (Grubb 1985, Tilman 1988, Grace 1993). Much as competitive intensity may vary in intensity with abiotic stress, the balance between facilitation and competition may also be affected by the harshness of the abiotic environment. Bertness and Callaway (1994) hypothesized that the importance of facilitation in plant communities increases with increasing abiotic stress or increasing consumer pressure, because neighbors buffer one another from extremes of the abiotic environment (e.g., temperature or salinity) and herbivory. Alternatively, they hypothesized that the importance of competition would increase when abiotic stress and consumer pressure were relatively low. Competition, by definition, involves a struggle to preempt resources such as light, water, or nutrients that, in turn, control carbon acquisition. Under physical conditions that permit rapid resource acquisition, competition should be intense. However, severe physical conditions (e.g., extreme cold, heat, salinity) may restrict the ability of plants to acquire these resources. Any amelioration of severe stress by neighbors may be likely to favor growth to a greate extent than competition for resources is likely to restrict growth.

There have been few direct tests of this abiotic stress hypothesis, but several studies support it. At the Alaskan floodplain site of Walker and Chapin (1987), soil nitrogen levels in early successional soil were 3-10 times higher than in soils on glacial moraines at the Glacier Bay, Alaska site (Chapin et al. 1994). The net effect of the nitrogen-fixing Alnus on Picea seedlings was facilitative on the moraine (high nutrient stress), but competitive on the floodplain (low nutrient stress). These experiments suggest that variation in abiotic stress caused by nutrient availability may alter the balance of competition and facilitation. However, the importance of facilitation at Glacier Bay may also be enhanced by low rates of nitrogen accumulation and a moist, moderate climate, all conditions that favor growth of vascular plants associated with symbiotic nitrogen fixers (Walker 1993, 1995). Furthermore, the facilitative effects of nitrogen fixers such as Alnus varies with their morphology, life-span, density, and successional stage (Walker 1993).

In a New England salt marsh, Bertness and Yeh 
(1994) found that the shrub Iva frutescens facilitated conspecific seedlings in saline soils by moderating soil salinity under its canopy. When salt stress was reduced by experimentally watering patches, strong competitive interactions developed between adults and seedlings, as well as among seedlings. Bertness and Shumway (1993) also eliminated the facilitative effects of Distichlis spicata and Spartina patens on Juncus gerardi by watering experimental plots and reducing soil salinity. In the same marsh, the fitness of Iva shrubs and Juncus gerardi was enhanced by the presence of neighbors at lower elevations, but was suppressed by neighbors at higher elevations, where soil salinity was lower (Bertness and Hacker 1994).

In an experiment examining facilitation and competition in the context of abiotic stress, Greenlee and Callaway (1996) used removal experiments to document shifts in interference and facilitation between growing seasons with different mean temperatures, rainfall, and cloud cover in a northern Rocky Mountain grassland. In a wet, cool (low-stress) year, bunchgrasses competed with Lesquerella carinata, a rare perennial mustard; in a dry, hot year, bunchgrasses facilitated Lesquerella. Overall, Lesquerella had a positive spatial association with bunchgrasses. Similarly, Hillier (1990), studying plant establishment in grasslands in England, found facilitative effects on dry, south-facing slopes, but competition on more mesic, north-facing slopes. Other studies that have examined the variation in productivity between sites and between years also suggest that competitive effects are stronger under wet, cool conditions, whereas facilitative effects are more evident in dry, hot years (Fuentes et al. 1984, De Jong and Klinkhamer 1988a, b, Frost and McDougald 1989, McClaran and Bartolome 1989, Belsky 1994).

In subalpine forests of the Bitterroot Mountains in northwestern Montana, Pinus albicaulis appears to vary in its effect on Abies lasiocarpa along a gradient of stress. Abies lasiocarpa trees are randomly distributed with respect to $P$. albicaulis in "low-stress" habitats characterized by high rates of tree growth and sheltered topography, but are clumped around $P$. albicaulis in "high-stress" sites characterized by low rates of tree growth and exposed topography (Callaway and Bertness 1994). Comparison of increment cores showed that the growth rates of mature A. lasiocarpa near pines decreased with the death of $P$. albicaulis in high-stress sites, but increased after the death of nearby $P$. albicaulis in low-stress sites. These data indicated that facilitation was more important between these subalpine forest dominants in high-stress environments, but that interference was more important in low-stress environments. Based on increment cores of solitary $P$. albicaulis vs. $P$. albicaulis with $A$. lasiocarpa neighbors, however, A. lasiocarpa had comparably intense competitive effects on $P$. albicaulis in both high-stress

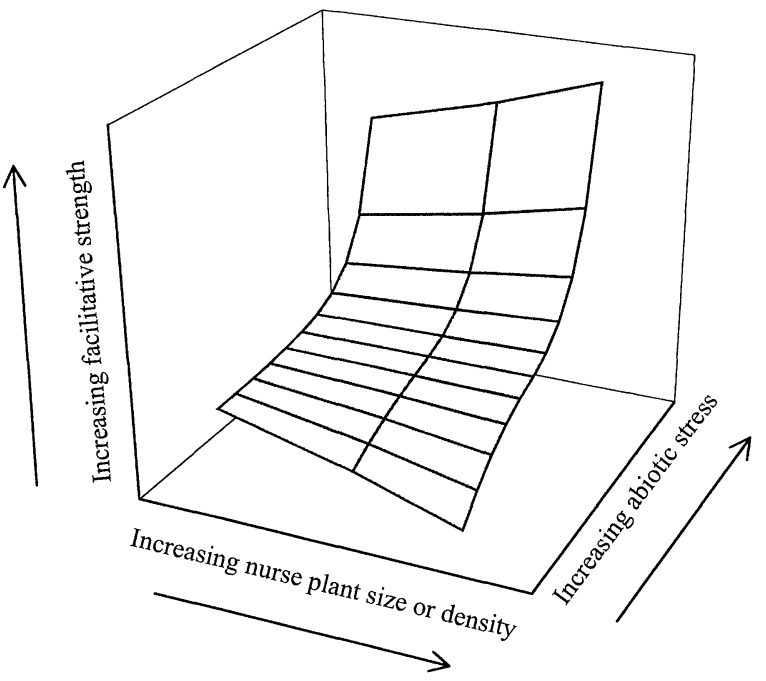

FIG. 1. Conceptual model of the effects of benefactor size, age, or density on the relative importance of positive and negative interactions on physical stress gradients. Under harsh physical conditions, increasing benefactor age, size, or density increases the relative strength of facilitation. Under benign physical conditions, increased benefactor age, size, or density increases the relative strength of the competitive effect.

and low-stress environments (R. M. Callaway, unpublished data).

The balance of competition and facilitation on gradients of physical stress may vary with the life stages of benefactors and beneficiaries. Size, density, or life stage of benefactors could have different effects at different points on the response curve of the consumer pressure-abiotic stress model of Bertness and Callaway (1994) (Fig. 1). We reanalyzed data from Callaway and Bertness (1994) to see if they complemented this conceptual model. At the low-stress and the high-stress sites, the densities of Abies seedlings, saplings, and adults under 70 Pinus canopies that varied from 0.35 to $18.0 \mathrm{~m}^{2}$ in projected area were measured and compared to Abies densities in 70 plots in open areas. Each open plot was paired with a subcanopy plot, and its size was adjusted so that it equaled that of its subcanopy pair. Regressions of density and sample area were statistically compared using ANCOVA between subcanopy and open samples within each site. Densities of Abies did not increase significantly with Pinus canopy size at the low-stress site, and the regression slope for subcanopy samples did not differ from that for open samples (Fig. 2). At the high-stress site, however, Abies density significantly increased with Pinus size, and differed significantly from the slope of the regression for open areas. These data circumstantially support the hypothesis that facilitation increases in intensity with benefactor size in abiotically stressful environments. However, neighbor size was not correlated with any neighbor pattern in less stressful environments. 

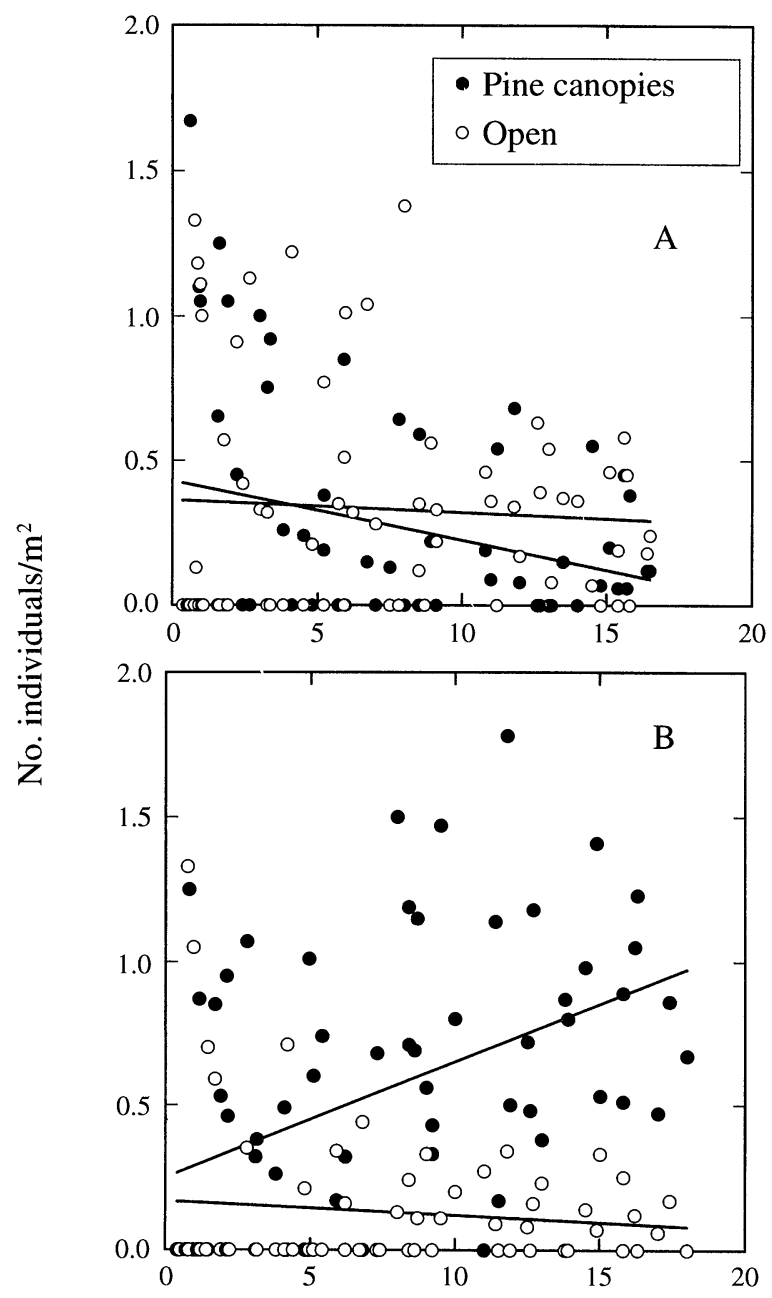

Area sampled $\left(\mathrm{m}^{2}\right)$

FIG. 2. The relationship between Abies lasiocarpa density and the canopy area of the overstory Pinus albicaulis, its apparent benefactor or competitor, compared to the relationship between A. lasiocarpa density and plot size in open areas. (A) Density-sample area relationships in "low-stress" sites; slopes did not differ significantly (ANCOVA, $P_{\text {microhabtat } \times \text { sample area }}>0.4$ ). (B) Density-sample area relationships in "high-stress" sites; slopes differed significantly (ANCOVA, $P_{\text {microhabitat } \times \text { sample area }}<0.01$ ).

\section{CONCLUSION}

Species interactions involve a complex balance of competition and facilitation. Competition has long been recognized as a force in structuring plant communities (Connell 1983, Schoener 1983), although its importance is still debated (Grime 1979, Tilman 1988, Grace and Tilman 1990). Facilitation, although recognized as important by early ecologists (e.g., Phillips 1909 , Clements 1916, Compton 1929), has not received as much attention until recently (see Callaway 1995). The relative importance of these two processes in structuring particular plant communities can best be understood by recognizing and experimentally evaluating the influence of such factors as abiotic stress, consumer pressure, life stage, age, and density on interaction strengths. These factors interact, and indirect effects may increase complexity. Long-term experiments, designed to examine the balance of competition and facilitation while varying physical stress and age, size, and density of benefactors or beneficiaries, would contribute much to a synthesis of competition and facilitation in community ecology.

\section{ACKNOWLEDGMENTS}

We thank Josh Tewksbury for comments on the manuscript and development of the conceptual model. These ideas were developed while the second author was supported by NSF Grant BSR-8811902 to the Terrestrial Ecology Division, University of Puerto Rico, and International Institute of Tropical Forestry (USDA Forest Service), as part of the Long-Term Ecological Research program in the Luquillo Experimental Forest. We thank two anonymous reviewers for thoughtful and detailed comments on the manuscript.

\section{Literature Cited}

Adler, F. R., and W. F. Morris. 1994. A general test for interaction modification. Ecology 75:1552-1559.

Aguiar, M. R., and O. E. Sala. 1994. Competition, facilitation, seed distribution, and the origin of patches in a Patagonian steppe. Oikos 70:26-34.

Aguiar, M. R., A. Soriano, and O. E. Sala. 1992. Competition and facilitation in the recruitment of seedlings in Patagonian steppe. Functional Ecology 6:66-70.

Aplet, G. H., R. K. Loh, J. T. Tunison, and P. M. Vitousek. In press. Experimental restoration of a closed faya tree stand. Technical Report, Cooperative National Park Resources Studies Unit, University of Hawaii at Manoa. National Park Service, Hawaii, USA.

Archer, S., and E. J. Rykiel. 1994. Similarities in vegetation cluster formation processes in contrasting savanna ecosystems (abstract). ISEM Symposium: facilitation, nurse plants, and nucleation: vegetation cluster processes driving plant succession. E. J. Rykiel Jr. (organizer). Program and Abstracts, 79th Annual ESA Meeting, Knoxville, Tennessee, USA

Archer, S., C. Scifres, C. R. Bassham, and R. Maggio. 1988. Autogenic succession in a subtropical savanna: conversion of grassland to woodland. Ecological Monographs 58:111127.

Arriaga, L., Y. Maya, S. Diaz, and J. Cancino. 1993. Association between cacti and nurse perennials in a heterogeneous dry forest in northwestern Mexico. Journal of Vegetation Science 4:349-356.

Belsky, A. J. 1994. Influences of trees on savanna productivity: tests of shade, nutrients, and tree-grass competition. Ecology 75:922-932.

Berkowitz, A. R., C. D. Canham, and V. R. Kelly. 1995. Competition vs. facilitation of tree seedling growth and survival in early successional communities. Ecology 76: 1156-1168.

Bertness, M. D., and R. M. Callaway. 1994. Positive interactions in communities. Trends in Ecology and Evolution 9:191-193.

Bertness, M. D., and S. D. Hacker. 1994. Physical stress and positive associations among marsh plants. American Naturalist 144:363-372.

Bertness, M. D., and G. H. Leonard. 1997. The role of positive interactions in communities: lessons from intertidal habitats. Ecology 78: 
Bertness, M. D., and S. W. Shumway. 1993. Competition and facilitation in marsh plants. American Naturalist 142: 718-724.

Bertness, M. D., and S. M. Yeh. 1994. Cooperative and competitive interactions in the recruitment of marsh elders. Ecology 75:2416-2429.

Billick, I., and T. J. Case. 1994. Higher order interactions in ecological communities: what are they and can they be detected? Ecology 75:1529-1543.

Callaway, R. M. 1992. Effect of shrubs on recruitment of Quercus douglasii and Quercus lobata in California. Ecology 73:2118-2128.

. 1994. Facilitative and interfering effects of Arthrocnemum subterminale on winter annuals in a California salt marsh. Ecology 75:681-686.

1995. Positive interactions among plants. Botanical Review 61:306-349.

Callaway, R. M., and M. D. Bertness. 1994. Gradients of physical stress and the relative importance of facilitation and interference. ISEM Symposium: facilitation, nurse plants, and nucleation: vegetation cluster processes driving plant succession. E. J. Rykiel Jr. (organizer). Program and Abstracts, 79th Annual ESA Meeting, Knoxville, Tennessee, USA.

Callaway, R. M., E. H. DeLucia, D. Moore, R. Nowak, and W. H. Schlesinger. 1996. Competition and facilitation: contrasting effects of Artemisia tridentata on Pinus ponderosa and $P$. monophylla. Ecology 77:2130-2141.

Callaway, R. M., and L. King. 1996. Oxygenation of the soil rhizosphere by Typha latifolia and its facilitative effects on other species. Ecology 77:1189-1195.

Callaway, R. M., N. M. Nadkarni, B. E. Mahall. 1991. Facilitation and interference of Quercus douglasii on understory productivity in central California. Ecology 72:14841499.

Campbell, B. D., and J. P. Grime. 1992. An experimental test of plant strategy theory. Ecology 73:15-29.

Chapin, F. S., III., L. R. Walker, C. L. Fastie, and L. C. Sharman. 1994. Mechanisms of primary succession following deglaciation at Glacier Bay, Alaska. Ecological Monographs 64:149-175.

Clements, F. E. 1916. Plant succession: an analysis of the development of vegetation. Carnegie Institution of Washington, Washington, D.C., USA.

Compton, R. H. 1929. The vegetation of the Karoo. Journal of the Botanical Society of South Africa 15:13-21.

Connell, J. H. 1983. On the prevalence and relative importance of interspecific competition: evidence from field experiments. American Naturalist 122:661-696.

- 1990. Apparent vs. "real" competition in plants Pages 9-26 in J. B. Grace and D. Tilman, editors. Perspectives on plant competition. Academic Press, New York, New York, USA.

Connell, J. H., and R. O. Slatyer. 1977. Mechanisms of succession in natural communities and their role in community stability and organization. American Naturalist 111:11191114.

De Jong, T. J., and P. G. L. Klinkhamer. 1988a. Seedling establishment of the biennials Cirsium vulgare and Cynoglossum officinale in a sand-dune area: the importance of water for differential survival and growth. Journal of Ecology 76:393-402.

De Jong, T. J., and P. G. L. Klinkhamer. 1988b. Population ecology of the biennials Cirsium vulgare and Cynoglossum officinale in a coastal sand-dune area. Journal of Ecology 73: $147-167$.

del Moral, R., and L. C. Bliss. 1993. Mechanisms of primary succession: insights resulting from the eruption of Mount St. Helens. Advances in Ecological Research 24:1-66.

DeLucia, E. H., W. H. Schlesinger, and W. D. Billings. 1988
Water relations and the maintenance of Sierran conifers on hydrothermally altered rock. Ecology 69:303-311.

Eldridge, D. J., M. Westoby, and K. G. Holbrook. 1991. Soil surface characteristics, microtopography, and proximity to mature shrubs: effects on survival of several cohorts of Atriplex vesicaria seedlings. Journal of Ecology 78:357364.

Ellison, L., and W. R. Houston. 1958. Production of herbaceous vegetation in openings and under canopies of western aspen. Ecology 39:338-345.

Fastie, C. L. 1995. Causes and ecosystem consequences of multiple pathways of primary succession at Glacier Bay, Alaska. Ecology 76:1899-1916.

Flores-Martinez, A., E. Ezcurra, and S. Sanchez-Colon. 1994 Effect of Neobuxbaumia tetetzo on growth and fecundity of its nurse plant Mimosa luisana. Journal of Ecology 82: 325-330.

Fowler, N. F. 1988. What is a safe site? Neighbor, litter, germination date, and patch effects. Ecology 69:947-961.

Franco, A. C., and P. S. Nobel. 1988. Interactions between seedlings of Agave deserti and the nurse plant Hilaria rigida. Ecology 69:1731-1740.

Franco, A. C., and P. S. Nobel. 1989. Effect of nurse plants on the microhabitat and growth of cacti. Journal of Ecology 77:870-886.

Frost, W. E., and N. K. McDougald. 1989. Tree canopy effects on herbaceous production of annual rangeland during drought. Journal of Range Management 42:281-283.

Fuentes, E. R., R. D. Otaiza, M. C. Alliende, A. Hoffman, and A. Poiani. 1984. Shrub clumps of the Chilean matorral vegetation: structure and possible maintenance mechanisms. Oecologia 62:405-411.

Goldberg, D. E., and A. M. Barton. 1992. Patterns and consequences of interspecific competition in natural communities: a review of field experiments with plants. American Naturalist 139:771-801.

Goldsmith, F. B. 1978. Interaction (competition) studies as a step toward the synthesis of sea cliff vegetation. Journal of Ecology 61:819-829.

Grace, J. B. 1993. The effect of habitat productivity on competition intensity. Trends in Ecology and Evolution 8:229230.

Grace, J. B., and D. Tilman. 1990. Perspectives on plant competition. Academic Press, New York, New York, USA

Greenlee, J., and R. M. Callaway. 1996. Effects of abiotic stress on the relative importance of interference and facilitation. American Naturalist 148:386-396.

Grime, J. P. 1979. Plant strategies and vegetation processes John Wiley, New York, New York, USA.

Grubb, P. J. 1985. Plant populations and vegetation in response to habitat disturbance and competition: problems of generalization. Pages 595-621 in J. White, editor. The population structure of vegetation. Dr. W. Junk, The Hague, The Netherlands.

Guevara, S., J. Meave, P. Moreno-Casasola, and J. Laborde. 1992. Floristic composition and structure of vegetation under isolated trees in neotropical pastures. Journal of Vegetation Science 3:655-664.

Guevara, S., E. Purata, and E. Van der Maarel. 1986. The role of remnant forest trees in tropical forest succession. Vegetatio 66:77-84.

Hay, M. E. 1986. Associational plant defenses and the maintenance of species diversity: turning competitors into accomplices. American Naturalist 128:617-641.

Hillier, S. H. 1990. Gaps, seed banks, and plant species diversity in calcareous grasslands. Pages 57-66 in S. H. Hillier, D. W. H. Walton, and D. A. Wells, editors. Calcareous grasslands: ecology and management. Bluntisham Books, Huntingdon, UK.

Holmgren, M., M. Scheffer, and M. A. Huston. 1997. The 
interplay of facilitation and competition in plant communities. Ecology 78:1966-1975.

Hunter, A. F., and L. W. Aarssen. 1988. Plants helping plants. Bioscience 38:34-40.

Huston, M. A. 1994. Biological diversity, the coexistence of species on changing landscapes. Cambridge University Press, Cambridge, UK.

Jordan, P. W., and P. S. Nobel. 1979. Infrequent establishment of seedlings of Agave deserti (Agavaceae) in the northwestern Sonoran Desert. American Journal of Botany 66: 1079-1084.

Jordan, P. W., and P. S. Nobel. 1981. Seedling establishment of Ferocactus acanthodes in relation to drought. Ecology 62:901-906.

Keddy, P. A., and B. Shipley. 1989. Competitive hierarchies in herbaceous plant communities. Oikos 54:234-241.

Kellman, M. 1985. Forest seedling establishment in Neotropical savannas: transplant experiments with Xylopia frutescens and Calophyllum brasiliense. Journal of Biogeography 12:373-379.

Kellman, M., and M. Kading. 1992. Facilitation of tree seedling establishment in a sand dune succession. Journal of Vegetation Science 3:679-688.

Kellman, M., and K. Miyanishi. 1982. Forest seedling establishment in Neotropical savannas: observations and experiments in the Mountain Pine Ridge savanna, Belize. Journal of Biogeography 9:193-206.

McAuliffe, J. R. 1984. Sahuaro-nurse tree associations in the Sonoran Desert: competitive effects of sahuaros. Oecologia 64:319-321.

- 1986. Herbivore-limited establishment of a Sonoran Desert tree: Cercidium microphyllum. Ecology 67:276-280.

- 1988. Markovian dynamics of simple and complex desert plant communities. American Naturalist 131:459490.

McClaran, M. P., and J. P. Bartolome. 1989. Effect of Quercus douglasii (Fagaceae) on herbaceous understory along a rainfall gradient. Madrono 36:141-153.

Miller, T. E. 1994. Direct and indirect species interactions in an early old-field plant community. American Naturalist 143: $1007-1025$.

Morris, W. F., and D. M. Wood. 1989. The role of lupine in succession on Mount St. Helens: facilitation or inhibition? Ecology 70:697-703.

Niering, W. A., G. D. Dreyer, F. E. Egler, and J. P. Anderson. 1986. Stability of a Viburnum lentago shrub community after 30 years. Bulletin of the Torrey Botanical Club 113: 23-27.

Niering, W. A., R. H. Whittaker, and C. H. Lowe. 1963. The saguaro: a population in relation to environment. Science 142: $15-23$

Pennings, S. C., and R. M. Callaway. 1992. Salt marsh plant zonation: the relative importance of competition and physical factors. Ecology 73:681-690.

Pennings, S. C., and R. M. Callaway. 1996. The role of a parasitic plant in community structure and diversity in a western salt marsh. Ecology 77:1410-1419.

Phillips, F. J. 1909. A study of pinyon pine. Botanical Gazette 48:216-223.

Pugnaire, F. I., P. Haase, J. Puigdefabregas, M. Cueto, S. C. Clark, and L. D. Incoll. 1996. Facilitation and succession under the canopy of a leguminous shrub, Retama sphaerocarpa, in a semiarid environment in southeast Spain. Oikos 76:455-464.

Rice, E. L. 1984. Allelopathy. Second edition. Academic Press, Orlando, Florida, USA.
Schoener, T. W. 1983. Field experiments on interspecific competition. American Naturalist 122:240-285.

Shirley, H. L. 1945. Reproduction of upland conifers in the Lake States as affected by root competition and light. American Midland Naturalist 33:537-612.

Smith, T. M., and M. A. Huston. 1989. A theory of the spatial and temporal dynamics of plant communities. Vegetatio 83: 49-69.

Steenberg, W. F., and C. H. Lowe. 1969. Critical factors during the first year of life of the saguaro (Cereus giganteus) at Saguaro National Monument. Ecology 50:825-834.

Steenberg, W. F., and C. H. Lowe. 1977. Ecology of the saguaro. II. Reproduction, germination, establishment, growth, and survival of the young plant. National Park Service Scientific Monograph Series Number 8. National Park Service, Washington, D.C., USA.

Tilman, D. 1988. Plant strategies and the dynamics and structure of plant communities. Princeton University Press, Princeton, New Jersey, USA.

Turner, R. M., S. M. Alcorn, and G. Olin. 1969. Mortality of transplanted saguaro seedlings. Ecology 50:835-844.

Turner, R. M., S. M. Alcorn, G. Olin, and J. A. Booth. 1966. The influence of shade, soil, and water on saguaro seedling establishment. Botanical Gazette 127:95-102.

Valiente-Banuet, A., A. Bolongaro, O. Briones, E. Ezcurra, M. Rosas, H. Nunez, G. Barnhard, and E. Vasquez. 1991a. Spatial relationships between cacti and nurse shrubs in a semiarid environment in central Mexico. Journal of Vegetation Science 2:15-20.

Valiente-Banuet, A., and E. Ezcurra. 1991. Shade as a cause of the association between the cactus Neobuxbaumia tetetzo and the nurse plant Mimosa luisana in the Tehuacan Valley, Mexico. Journal of Ecology 79:961-971.

Valiente-Banuet, A., F. Vite, and J. A. Zavala-Hurtado. $1991 b$. Interaction between the cactus Neobuxbaumia tetetzo and the nurse shrub Mimosa luisana. Journal of Vegetation Science 2:11-14.

Vetaas, O. R. 1992. Microsite effects of trees and shrubs in dry savannas. Journal of Vegetation Science 3:337-344.

Walker, L. R. 1993. Nitrogen fixers and species replacements in primary succession. Pages 249-272 in J. Miles and D. W. H. Walton, editors. Primary succession on land. Blackwell Scientific, Oxford, UK.

1994. Effects of fern thickets on woodland development on landslides in Puerto Rico. Journal of Vegetation Science 5:525-532.

. 1995. How unique is primary plant succession at Glacier Bay? Pages 137-146 in D. R. Engstrom, editor. Proceedings of the Third Glacier Bay Science Symposium, 1993. National Park Service, Anchorage, Alaska, USA.

. In press. Patterns and processes in primary succession. In L. R. Walker, editor. Ecosystems of disturbed ground. Elsevier, Amsterdam, The Netherlands.

Walker, L. R., and F. S. Chapin, III. 1987. Physiological controls over seedling growth in primary succession on an Alaskan floodplain. Ecology 67:1508-1523

Walker, L. R., and P. M. Vitousek. 1991. An invader alters germination and growth of a native dominant tree in Hawai'i. Ecology 72:1449-1455.

Williamson, G. B. 1990. Allelopathy, Koch's postulates, and the neck riddle. Pages 143-162 in J. B. Grace and D. Tilman, editors. Perspectives on plant competition. Academic Press, New York, New York, USA.

Wood, D. M., and R. del Moral. 1987. Mechanisms of early primary succession in subalpine habitats on Mount St. Helens. Ecology 68:780-790.

Wootton, J. T. 1994. Putting the pieces together: testing the independence of interactions among organisms. Ecology 75: $1544-1551$. 